\title{
Analysis of the application of E-Invoicing in increasing Taxable Enterpreneur compliance
}

\author{
Harianto Harianto †, Abdul Rahman Mus 2, Darwis Lannai 3 \\ Universitas Muslim Indonesia, Urip Sumohardjo KM.5 Street, Panaikang, Makassar, 90231, South Sulawesi, Indonesia
}

\begin{tabular}{|c|c|}
\hline Submission Info : & Abstract \\
\hline $\begin{array}{r}\text { Editor: Muhammad Nasrun } \\
\text { Received } 25 \text { July } 2020 \\
\text { Accepted } 29 \text { July } 2020 \\
\text { Available online } 30 \text { July } 2020\end{array}$ & $\begin{array}{l}\text { This study aims to examine the application of e-invoices to the compliance } \\
\text { of Taxable Entrepreneurs (PKP) registered at KPP Pratama Makassar } \\
\text { Selatan. This research is a qualitative descriptive study. Data sources are } \\
\text { primary data obtained from interviews with Tax Entrepreneurs (PKP) and }\end{array}$ \\
\hline $\begin{array}{r}\text { Keyword : } \\
\text { E-Invoices } \\
\text { Effectiveness } \\
\text { Efficiency } \\
\text { Compliance } \\
\text { Taxable Enterpreneur }\end{array}$ & $\begin{array}{l}\text { Tax Officers. This study uses four informants consisting of three } \\
\text { informants from taxable entrepreneurs (PKP) and one informant from the } \\
\text { Supervision and Consultation Section. Data analysis uses descriptive } \\
\text { analysis method. The results showed that the application of e-invoicing } \\
\text { within the scope of the South Makassar Primary Tax Office was effective } \\
\text { and efficient. The implementation of e-invoicing increases taxpayer } \\
\text { compliance, although there are some obstacles experienced by taxable } \\
\text { entrepreneurs in using e-invoices, namely internet connection problems, } \\
\text { and the application of errors sometimes occurs. }\end{array}$ \\
\hline $\begin{array}{r}\text { antohasnur@gmail.com } \\
\text { abdul.rahmanmus@umi.ac.id } \\
\text { darwis.lannai@umi.ac.id }\end{array}$ & $\begin{array}{l}(c) \text { EY } \\
\text { This is an open access article under the CC BY } 4.0 \text { International License } \\
\text { (C) Point of View Research Accounting and Auditing (2020) }\end{array}$ \\
\hline
\end{tabular}

\section{Introduction}

Once the magnitude of the role of tax in the State Budget for the Indonesian State, efforts to increase tax revenues continue to be carried out by the government which in this case is the duty of the Directorate General of Taxes (Widayati \& Nurlis, 2010; Sudirman \& Muslim, 2018). Therefore, to support the increase in tax revenue, the Directorate General of Taxes always makes improvements to the organizational structure and services (Amah et al., 2010). This is done because the state needs the availability of funds to finance government needs in the framework of national development (Prahaji et al., 2015). The Government of Indonesia has stipulated Regulation of the Director General of Tax Number PER-16 / PJ / 2014, which took effect on July 1, 2014, as the basis for implementing the Tax e-invoice. The application of tax e-invoices has advantages and benefits that are not only felt by the Directorate General of Taxes and Tax Service Officers but also by PKP. Electronic systems for tax administration include e-filing, e-billing and e-invoicing. e-invoicing is useful for taxpayers to obtain electronic tax invoices provided by the tax directorate and used as proof after online tax 
payment. The use of e-invoices is intended to provide convenience, comfort and security for taxable entrepreneurs in carrying out tax obligations (Husnurrosyidah \& Suhadi, 2017). But in reality there are still many taxpayers who do not yet have an awareness of the importance of fulfilling tax obligations both for the state and for themselves as good citizens and this causes all the potential tax that has not been explored to the maximum (Allolayuk, 2018).

State revenue from the taxation sector has not been maximized, one of the causes is tax administration which tends to be complicated. This is very closely related to the low motivation of taxpayers to carry out their obligations in paying taxes (Nurjanah et al., 2017). According to Rahayu \& Lingga, (2009) Tax is something that is dynamic and follows the development of social and economic life of the country and its people. This has triggered an increase in demands for increased revenue, improvements and fundamental changes in all aspects of taxation as a reason for tax reformation from time to time, in the form of improvements to taxation policies and tax administration systems, so that the tax base can be expanded, so that the potential for tax revenue available can be collected optimally by upholding the principle of social justice and providing excellent service to taxpayers.

The application of e-Invoices is intended to provide convenience, comfort, and security for taxable entrepreneurs in carrying out their tax obligations (Lintang \& Pusung, 2017). The use of e-invoices protects Taxable Entrepreneurs (PKP) from misuse of tax invoices by non-PKP. In addition, PKP can also save time, energy and costs when implementing VAT e-invoices. PFM can reduce the cost of printing the tax invoice. PKP can also save time and energy because the tax submission can be done anywhere and anytime by accessing the Tax e-invoice menu that has been provided online at the Directorate General of Tax's website. Because the use of e-invoices is done online, it is possible to utilize, create and report e-invoices in real time. So by using tax e-invoices, PKP no longer needs to print paper invoices and PKP does not have to go to the Tax Service Office to report it (Said, S., \& Aslindah, 2018).

Basically, the process for filling SPT through an electronic system is not as easy as we imagine. This happens because we must fully understand the mechanism or how to use it in an effort to submit the tax return (SPT) electronically first (Yanto \& Dewi, 2020). Operational activities are said to be effective if the activity process reaches the final goals and objectives of the policy (Mardiasmo, 2009). Indicators of effectiveness include the accuracy of use, use and support goals. An indicator of the accuracy of use, that is, what has been determined in terms of use already represents what was expected beforehand related to the process. Then the outcome indicators to illustrate the output of the process of activities carried out whether it will give a good change and have the expected results. Whereas indicators supporting the objectives relate to output in accordance with planned activities and expected goals.

Efficiency refers to the proper use of available resources (without waste) in order to achieve optimal results. Pandiangan (2014) defines efficiency in terms of taxpayers is that the costs incurred by taxpayers for taxation purposes are very minimal, in accordance with the proper amount, and do not violate the law. In accordance with Minister of Domestic Affairs Regulation number 13 of 2006, efficiency is the relationship between input and output. Starting from a number of these definitions, the researcher provides an opinion that the efficiency of implementing e-invoicing is the accuracy of using resources (energy, cost, time) as input in implementing einvoicing with the aim of achieving outputs whose benefits are felt not only by the Director General of Taxes and KPP but also by the taxpayers.

Several studies on the efficiency or effectiveness of tax administration modernization have been carried out, such as the Asriningsih \& Naniek (2014) research which proves that there is an effect of the application of eSPT on the efficiency of tax data processing. The number of taxpayers who have been confirmed as PKP and Taxpayers of the e-invoicing facility that has been confirmed as PKP in 2016-2018 in South Makassar KPP is presented in table 1.

Table 1. Taxable Entrepreneurs for 2016-2018 KPP Pratama South Makassar

\begin{tabular}{ccc}
\hline Year & PKP Registered & Taxable Entrepreneurs e-invoice user \\
\hline 2016 & 4.107 & 2.922 \\
2017 & 4.491 & 2.939 \\
2018 & 4.909 & 3.114 \\
\hline
\end{tabular}

Source: KPP Pratama South Makassar, (2020) 
Tax revenue that continues to increase does not seem to be balanced with an increase in taxpayer compliance in Indonesia, this is reflected through the realization of tax revenues that have not been optimal compared to the existing potential (Prahaji, 2013). The self assessment system that is applied always gives trust and responsibility to taxpayers to calculate, deduct, deposit and report the amount of tax owed in accordance with tax provisions, in carrying out its obligations, taxpayers have the willingness to fulfill their tax obligations in accordance with applicable regulations without the need for inspection, careful investigation, warning, or threat and the application of sanctions both law and administration (James \& Nobes, 1996). The Value Added Tax collection system implemented in Indonesia currently separates between Commercial Invoice and Tax Invoice so as to facilitate Taxpayers who make use of loopholes that are against the law (Yamin \& Putranti, 2009). This in turn requires taxpayers to uphold the value of honesty and integrity in fulfilling their tax obligations.

The urgency of this study is that taxpayer compliance is an important aspect to be studied after the entry into force of the self assessment system which gives full authority to taxpayers to calculate, pay and report their tax obligations (Tiraada, 2013). Tax compliance will produce many benefits, both for the tax authorities and for the taxpayer himself as the holder of this important role. For the tax authorities, tax compliance can ease the duties of tax officials, officers do not do too many tax audits and of course tax revenue will get optimal results. Whereas for Taxpayers, the benefit obtained from tax compliance is the granting of a deadline for issuing a Tax Exemption Return Return Decree (SKPPKP) no later than three months from the request for overpayment of taxes submitted by the Taxpayer received for PPh and one month for VAT, without going through research and inspection by the Directorate General of Taxes (Rahayu, 2010).

The concept of this research is related to the theory of obedience which explains a condition in which a person is obedient to the commands or rules given. According to Tahar \& Rachman (2014) compliance regarding taxation is a responsibility to God, the government and the people as taxpayers to fulfill all tax obligations and carry out their taxation rights. Taxpayer Compliance is a behavior that is based on the awareness of a Taxpayer on his tax obligations while still based on the laws and regulations that have been set.

This study focuses on the application of e-invoicing as a form of tax administration modernization that supports Taxable Entrepreneurs (PKP) in carrying out their tax obligations. Motivation of this research is because the number of Taxable Entrepreneurs in Indonesia continues to increase and the potential tax revenue (both Value Added Tax and Sales Tax on Luxury Goods) is very large from the PKP. This study aims to determine whether the application of e-invoicing has been effective and efficient to support the implementation of tax obligations by Taxable Entrepreneurs (PKP), so that taxpayer compliance (specifically PKP) can be increased. This study was conducted on Taxable Entrepreneurs registered at the Makassar South Makassar KPP, considering that the Makassar area is very potential because there are many micro, small, and medium scale entrepreneurs both registered as PKP and potentially registered as PKP. As of the beginning of 2018 there were 4,909 Taxable Entrepreneurs (PKP) registered at the South Makassar KPP.

\section{Research Method}

This type of research is descriptive qualitative to understand the phenomenon of research in a natural context and by utilizing various natural methods (Moleong, 2010). According to Syah, (2010) descriptive research is a research method used to find the broadest possible knowledge of the object of research at a particular time. According to Setyosari (2016) which explains that descriptive research is research aimed at. explain or describe a situation, event, object whether a person, or everything related to variables that can be explained both with numbers and words. This study uses primary data by conducting interviews with competent parties and the use of tax e-invoices to obtain an overview of Electronic Tax Invoice (e-invoicing) and its application (Sugiyono, 2010). This study uses four informants consisting of three informants from taxable entrepreneurs (PKP) and one informant from the Supervision and Consultation Section

\section{Result and Discussion}

\section{Result}


Electronic Invoice (e-invoice) Value Added Tax is a government policy made by the Directorate General of Taxes stipulated in the Regulation of the Directorate General of Tax PER-16 / PJ / 2014 regarding the procedures for making and reporting tax invoices in electronic form. VAT e-invoice as a refinement of a paperbased invoice where the e-invoice is also a proof of tax collection on transactions that occur against Taxable Goods (BKP) and or Taxable Services (JKP) by Taxable Entrepreneurs (PKP). E-invoices make it possible to detect and reduce the presence of fictitious invoices or transactions from fictitious companies.

The enactment of this e-invoice began on July 1, 2014, but not all PKP have implemented it, only around 45 PKP. As of July 1, 2016 this e-invoice was applied to all PKP in Indonesia. It's been around 4 years, this einvoice has been implemented. During the 4 years of enactment of e-invoices, it turns out there are still improvements and improvements with the aim that both the DGT and the Tax Office can provide the best service to taxpayers in this case are taxable entrepreneurs. It is always sought because both DGT and KPP have the hope that taxpayers will be obedient to fulfill their tax obligations. In order to increase taxpayer compliance, especially taxable entrepreneurs, the implementation of e-invoices must be ensured effective and efficient in its application.

\section{Discussion}

Accuracy of Use

E-invoicing is expected to be used in accordance with the purpose of its manufacture, namely to provide convenience, comfort, and security for Taxable Entrepreneurs (PKP) in carrying out their tax obligations by utilizing technology (Rifani et al., 2019). In addition, the application of e-invoicing also aims to improve the VAT administration system, which has so far still applied a manual system in issuing Tax Invoice by taxpayers. Following are the results of interviews with several research informants:

Supervision and Consultation Section (Waskon) 1:

Waskon 1 "E-Invoice PPN can carry out the function as proof of tax collection more precisely as administration. An invoice becomes a legality of a transaction. This invoice is also a billing invoice for Value Added Tax and is equivalent to the SSP".

From the Waskon 1 statement, information was obtained that the VAT e-invoice has the same function as a manual invoice, namely as a proof of tax collection or as administering. This invoice becomes the legality of the transaction and becomes a charge on VAT and has the same function as the SSP. The existence of einvoicing is also felt by Taxable Entrepreneurs (PKP) 1 as part of who also uses the e-invoice. One taxable user said that:

Taxable Entrepreneur (PKP)

PKP 1 "The existence of an e-invoice that replaces the previous invoice has the same function to find out the receipt and become proof of tax collection in this case the Value Added Tax (VAT) when we conduct or carry out transactions (sales or purchases) that give rise to input or VAT Output VAT, EInvoice is also to maintain the legality of the transaction in accordance with applicable tax provisions.

PKP 2 "E-invoices can be used as proof of VAT collection. This e-invoice is a valid invoice received by the tax office and the DGT. This E-Invoice is actually being actively applied to replace the paper invoices used so far. Therefore, it can be a proof of VAT collection, whether output VAT or Input VAT ".

The PKP 1 and PKP 2 and Waskon 1 statements indicate that e-invoices that replace the previous invoice have the same function. The difference from the previous paper invoice is only the physical form of the invoice. The existence of e-invoices provides convenience in processing tax receipts by tax parties who collect tax with PKP.

PKP 1 "Since the e-invoicing, I have felt comfortable using it mainly supported by existing government regulations".

PKP 2 "With e-invoicing the calculation process of Value Added Tax (VAT) becomes quick and easy". Waskon 1 "The emergence of e-invoices makes it easy for PKP to find out their VAT so that we can easily calculate the VAT that should be received"

This information shows that the existence of e-invoices greatly facilitates PKP in processing their VAT, especially supported by regulations issued after this e-invoice appears. This information explains that both the recipient and taxpayers feel the good impact of this e-invoice. VAT can be calculated by PKP and makes it easy 
for them to enter tax and the tax party is able to calculate the VAT received by the PKP concerned. From the first indicator that the accuracy of use makes it clear that the use of tax e-invoices provides convenience not only to tax officials but also to PKP. This convenience should improve the performance of tax officials. As well as increasing PKP compliance, especially in terms of administration referred to as tax reporting.

Use Results

The results to illustrate the output of the process of activities carried out whether it will give a good change and have the expected results. This indicator explains the changes that are better than before in terms of their use.

Waskon 1 "E-invoices can be more supervising between who is the buyer and who is selling where previously using paper invoices that are easy to change in this case invoices can be fictitious."

PKP 1 "E-invoices are better than paper invoices because I don't need to fill out paper forms anymore. I can also print the invoice if it's not printed, it's fine".

PKP 3 "By using e-invoicing can minimize the calculation errors made. In addition, the use of e-invoices also does not waste a lot of paper".

Based on the results of the interviews, information was obtained that e-invoices were present in lieu of paper invoices that could be changed according to PKP requirements. For the government, the existence of einvoicing can be a supervisor between the entrepreneur who buys the item and the entrepreneur who sells the item. For Taxable Entrepreneurs (PKP), they feel the ease of having this e-invoice reinforces the Waskon 1 statement if the e-invoice is better than a paper invoice. PKP can more easily fill out the invoice form because it has been stored by the e-invoicing system permanently. PKP also does not need to print e-invoices, thus saving paper usage. Besides PKP felt the presence of e-invoicing minimized the calculation error. Based on information from the speakers it can be concluded that the use of tax e-invoices is better than paper invoices because it has many advantages between being more secure, comfortable, saving energy, time and filing space because it can be stored in laptops or hard drives and other storage.

Tax e-invoices also provide ease of processing Taxpayer data and easily and securely access, tax e-invoices are easy to access by PKP and accessed data is stored securely by the system.

PKP 1 "E-invoicing makes it easy to access data security data, I think it is safe enough to access or use e-invoices because PKP has their own account and password. Constraints that arise sometimes are caused by internet networks".

PKP 2 "Using e-invoices is safe because to access e-invoices each PKP uses its own account that is already registered with the Tax Office".

The PKP 1 and PKP 2 statements indicate that e-invoices are easily accessed and the data entered can be stored securely with their respective accounts. The obstacles sometimes faced by PKP in the form of internet networks in accessing e-invoicing systems are not good. In addition to the security felt by the PKP, the tax control party also felt the same as expressed by Waskon 1 that:

Waskon 1 "E-invoices are able to assist in supervising Taxable Entrepreneurs (PKP) in tax payments".

From the interviews, it was obtained information that the use of tax e-invoices facilitates the processing of taxpayer data, especially tax officers to supervise PKP, ease of access is still constrained in internet network problems that are sometimes poor and application or system problems that sometimes experience errors This is an input for the DGT and KPP to make improvements to the system that has been made while the security of e-invoice user access has guaranteed secure access to PKP. because PKP has its own account and password.

Supporting Goals

Supporting objectives related to outputs according to planned activities with expected goals. Tax e-invoices can maximize tax revenue (for the tax authorities) and provide convenience in tax submission (for PKP).

Waskon 1 "E-invoices help us to monitor which ones have not yet been paid, as well as $2 \%$ sanctions which are payable $2 \%$ × 2 x principally".

PKP 1 "Tax e-invoices can provide convenience in tax submission because they only enter transaction data in the application provided". 
PKP 2 "Submission or reporting of taxes becomes easy and fast because we do not need to go to the tax office anymore, as the PKP, all we have to do is input the data into the available menu and follow the application instructions".

PKP 3 "E-invoicing provides convenience in tax delivery. I only need to input data related to transactions that occur in my business".

The results of this interview provide information that for the government, e-invoicing can function as a supervisor of all PKP activities and even sanctions PKPs who have not paid through the data in the e-invoicing system. From the interview results above, it can be seen that the tax e-invoice provides convenience in tax submission because PKP only needs to input / enter data related to transactions that occur in their business, especially related to the supply of Taxable Goods or Taxable Services. It's just that the convenience of einvoicing users is hampered by network problems or bad internet connections. This information shows that the application of e-invoicing within the Makassar South Tax Office has been effective. This is known from the achievement of the three indicators that include the accuracy of use, the results of use, and support the objectives. Tax recipients and tax submissions have felt easier since this e-invoice. Supported by special regulations after the issuance of this e-invoice makes legal implementation more secure and stronger in the eyes of the general public.

To assess the efficiency of the use of electronic tax invoices (e-invoices) to improve taxable businessman compliance (PKP) registered at KPP Pratama South Makassar. 7 indicators are used to measure the efficiency of using tax e-invoices.

E-invoices save time on invoicing or charging

The application of this tax e-invoice has advantages and benefits that are not only felt by the Directorate General of Taxes and Tax Service Officers but also by PKP. Using e-invoices can save time, effort and costs when implementing VAT e-invoices. PKP can save time and energy because the tax submission can be done anywhere and anytime by accessing the Tax e-invoice menu that has been provided online at the Directorate General of Taxes website. Because the use of e-invoices is done online, it is possible to utilize, create and report e-invoices in real time.

PKP 1 "Since using e-invoicing, all data is quickly completed because we only need to enter transaction data in the system so that we can save time, in addition to the e-invoicing application, our transactions have been recorded".

PKP 2 "Since using e-invoices, I only need to input transaction data into the e-invoicing application and when errors occur, corrective actions can also be done quickly".

PKP 3 "Filling in invoices using e-invoices saves me a lot of time because I only have to input transaction data that occurs at my company".

PKP 1 and PKP 2 statements indicate that e-invoices can save time in inputting, the data inputted is also directly stored by the system and the erroneous data can be directly corrected by the parties concerned. PKP Statement 3 shows that filling out invoices via e-invoices is very time-saving because it can be done anytime and anywhere. PKP does not need to visit the KPP to fill it. This result shows that tax e-invoice users save time to fill / create invoices because PKP recapitulates transaction data and then inputs the data into the application. The advantage of using this e-invoice is that the company that opposed the transaction has been recorded in the e-invoice and then when an error occurs, corrective action can be immediately implemented.

Tax e-invoices can save time and save energy when submitting or reporting.

PKP 2 "Filling in e-invoice data depends on the internet connection, if it's good then we can save time while saving energy when reporting I don't need to go to the tax service office anymore, I just need to work at the office in front of an internet connected laptop".

PKP 3 "Since using e-invoices, I can save time and effort when reporting, filling e-invoices e-invoices can be faster depending on the internet network".

PKP 2 and PKP 3 statements indicate that currently filling via e-invoice can save energy because PKP no longer needs to go to the Tax Service Office. PKP only needs to fill it in where they feel as long as the network or internet connection is good at that time. 
Waskon 1 "Through e-invoicing, payment is validated before being reported. WP does not need to go to the Tax Office to submit a report, because the reporting of e-invoices can go through the DGT official website".

This expression is in line with the statement of PKP 2 and PKP 3 that in filling the invoices of the WP / PKP no longer need to come to the Tax Office, the data only needs to be filled on the official website of the Directorate General of Taxes. From the results of the interview, it can be seen that the e-tax invoice can save time and effort when submitting or reporting. A good internet connection is very supportive of PKP to access e-invoices and other menus related to the submission of reports online, so that taxpayers do not need to go to the Tax Office enough in their respective offices.

The use of e-invoices can guarantee the accuracy of the data which includes transaction data and PKP data. Einvoices protect data that has been inputted by PKP so that the data is guaranteed to be correct.

Waskon 1 "Transactions via e-invoices must be approved by the seller and buyer. In the Profile there is a location survey that can ensure that the company is not fictitious. There is a digital certificate, then if there is an error in the transaction it will be rejected".

PKP 2 "E-invoices can guarantee the accuracy of transaction data, if you use e-invoices we or other companies cannot make transactions with fictitious companies. If something like that is sure to be easily detected by the system".

Waskon 1's opinion shows that the use of tax e-invoices guarantees the accuracy of the data. The use of einvoicing will minimize errors, and can detect if there are fictitious transactions with fictitious companies.

The use of e-invoicing can guarantee the security and confidentiality of data. E-invoices protect data that has been inputted by PKP so that the data is guaranteed security. This is felt by PKP 1 which states that:

PKP 1 "If you use an e-invoice there is a digital signature, then each PKP has its own account, with einvoicing also every time there is a transaction with a fictitious company it will be discovered soon so I think the data will be safe, confidential or my personal data as well. secure".

PKP 2 "Data security especially when making transactions is guaranteed by using e-invoicing. This is because e-invoices use digital signatures in the form of barcodes. I am sure that the data that has been recorded and entered in the KPP data bank will be kept confidential".

Waskon 1 "The use of e-invoices can guarantee the security and confidentiality of data, but then return to WP PKP to apply for a digital certificate".

From the interview results it can be seen that the use of e-invoices can guarantee the security and confidentiality of the power because the e-invoices already use barcodes as digital signatures and digital certificates, as well as the data entering PKP data banks must be kept confidential because surely tax officers hold codes his professional ethics.

The use of e-invoices is more cost effective compared to paper invoices. The presence of these e-invoices saves in terms of material use because PKP may or may not print the results of their e-invoices.

PKP 1 "E-invoices are more efficient than previous invoices because the use of e-invoices gives us the choice as taxable entrepreneurs (PKP) to print invoices or not. This means we can save money on paper and ink purchases".

Waskon 1 "E-invoicing is more cost-effective, because it can reduce paper usage and costs incurred. Expenditures for e-invoices are smaller than the perceived benefits".

From the interviews, it can be concluded that the use of e-invoices is more cost effective because it can reduce costs incurred for the procurement of paper and ink.

Utilization of e-invoices saves more on file storage space. The presence of these e-invoices saves in terms of material use because PKP may or may not print the results of their e-invoices. This means that e-invoicing can save available storage space.

PKP 1 "By using e-invoices we don't need a lot of special places to store invoice archives, what we need is storage on a computer in the form of soft files. If it's in the form of a soft file like this for me it will be easier to find it again when we need the e-invoice information ". 
PKP 2 "E-invoicing greatly saves storage space. In the past when I was still using paper invoices, I had to save them in the ordner, then I also store them in the file cabinet now with e-invoices, I only need computer memory for archiving soft files. "

From the interview results, it can be concluded that the use of e-invoices saves more on archival storage space because e-invoices as tax evidence can be stored in soft files, data in the form of soft files is also easy to find if needed for related information.

The use of e-invoices makes it easier to create VAT invoices, and makes it easier to fill out and report VAT eSPT. Through e-invoicing, PKP can directly create a VAT e-SPT report. This was revealed by Waskon 1 who stated that:

Waskon 1 "PKP only needs to input data related to the supply of Taxable Goods and or Taxable Services. As long as the internet network is in good condition it will be easy to fill out and report. Moreover, the menu available on the DGT website is equipped with manual filling ".

PKP 2 "E-invoicing makes it easier to make VAT invoices faster, I don't even need to number because they are already available on the application. When reporting becomes easier, there's no need to bring more files. In essence, as long as this application is supported by a good internet network, reporting can be done quickly.

PKP 3 "It's very easy, we don't need to make or number it because it's already available on the application, besides that e-invoice users also support the convenience of filling out e-SPT.

From the results of the interview, it can be concluded that the use of e-invoices makes it easier to create VAT invoices and also makes it easier to fill out and report VAT E-SPT.

The application of e-invoicing requires a smaller cost than the taxation receipt.

Waskon 1 "Since there is an e-invoice the use of the difference fees is very far, certainly greater KPP receipts when compared to the costs incurred. We have an internet IT team so we don't have to pay extra to hire the services of an outside IT team or even buy applications from outside ".

From the results of Waskon 1's statement, it is known that the costs incurred to implement e-invoicing are less because all implemented by the internal team the cost savings can be achieved this is efficient in terms of the ratio between costs and benefits that can be achieved.

The application of tax e-invoices (VAT e-invoices) increases the realization of Value Added Tax revenue from the Tax Office. This can be seen from the statement from Waskon 1 which states that:

Waskon 1 "There was an increase in revenue, with the use of e-tax invoices there was an increase to $90 \%$ of revenue from the entire PKP while with the paper invoice only 50\% of the revenue from all PKP".

From the results of Waskon 1's statement, it is known that the application of VAT e-invoices has an impact on increasing the value added tax receipts by about $90 \%$ of VAT receipts from KPP users of e-invoices. Based on the description above, the researcher concludes that the application of e-invoicing within the South Makassar Primary Tax Office has been efficient. It is known that seven indicators for measuring efficiency have been achieved. The application of e-invoicing in South Makassar KPP is already efficient. As a reinforcement of the facts, there are additional indicators to measure efficiency, namely the comparison between the costs incurred for implementing e-invoices with the revenue or benefits felt by the Tax Office. The data obtained states that the costs incurred are smaller / cheaper than tax revenue, tax revenue has increased.

The use of Electronic Invoices (e-invoices) increases tax compliance for Taxable Entrepreneurs (PKP) registered at KPP Pratama South Makassar

Enforcement of tax e-invoices that is effective and efficient and provides more benefits not only in terms of the DGT or KPP but also provides more benefits to PKP will ultimately increase the Compliance of PKP special taxpayers in carrying out their tax obligations. Taxable Entrepreneur Compliance is a process of activity (fulfillment of taxation obligations and acquisition of Taxable Entrepreneur taxation rights) in accordance with those stipulated in the Taxation Law. To find out the Taxpayer Compliance in this case the Taxable Entrepreneur as a result of effective and efficient e-invoicing, the indicators used include; Taxpayers register themselves at the Tax Service office to be confirmed as Taxable Entrepreneurs, Taxable Entrepreneurs Calculate taxes arising from their business, Taxable Entrepreneurs calculate independently VAT by utilizing 
tax e-invoices, Taxable Entrepreneurs pay underpaid VAT in a timely manner, and Taxable Entrepreneurs independently calculate VAT using tax e-invoices.

Taxpayers register themselves at the Tax Service office to be confirmed as a Taxable Entrepreneur. From this process the e-invoicing system will validate WP data as PPK.

PKP 1 "I registered as a Taxable Entrepreneur (PKP) to the tax service office and got an explanation from the tax official regarding e-invoicing".

PKP 2 "I registered myself and my business as a Taxable Entrepreneur at first I thought not to register but after getting an explanation I immediately registered as PKP".

From the interview, it can be seen that Taxable Entrepreneurs are compliant when viewed in terms of their willingness and volunteerism to register themselves as Taxable Entrepreneurs (PKP).

PKP is expected to be able to calculate their own taxes to be paid from their businesses so that there is transparency between PKP and KPP. As for those who are still troubled, KPP officers will help.

PKP 1 "I calculate my own VAT tax from my business transactions, if there are difficulties that I experience I can ask for help AR or tax officials who understand tax invoices".

PKP 2 "In calculating business taxes, I am usually assisted by employees in calculating my business transactions".

From the results of the interview, it can be seen that the Taxable Entrepreneur is quite compliant, because the Taxable Person for VAT purposes seeks to calculate the tax arising from his own business and when there is difficulty the PKP has the initiative to ask questions or consult with competent tax officials.

Through e-invoicing, PKP can calculate their own taxes to be paid from their businesses. This makes it easier for PKP to be able to calculate the range of tax costs incurred.

PKP 1 "I am greatly helped by the existence of this tax e-invoice. I can independently calculate transactions that occur at my company".

PKP 2 "With this tax e-invoice, both I and the employees can independently calculate input VAT and output VAT".

From the interviews, it can be seen that Taxable Entrepreneurs can independently calculate taxes, especially VAT by utilizing tax e-invoices, e-tax invoices provide convenience to PKP to calculate taxes.

Taxable Entrepreneurs pay underpaid VAT in a timely manner.

Through e-invoicing, PKP can find out before the tax due date must be paid. This makes PKP able to pay on time with the appropriate cost range.

PKP 1 "Ease of user e-invoicing, and speed of tax calculation really support me immediately to pay VAT".

PKP 3 "I try to pay taxes on time, to avoid delays because if you are late you will be fined."

From the results of the interview, it can be seen that Taxable Entrepreneurs always try to pay taxes, especially VAT, not on time. Moreover, tax e-invoices that provide facilities that support tax payments can be more timely, before the specified deadline.

Taxable Entrepreneurs submit their tax returns completely and on time before the deadline for submission.

E-invoices can be accessed anytime, anywhere. This allows PKPs to always check their schedule or due date to avoid payment of fines.

PKP 2 "Even though we are always constrained by network problems, we and our forgetfulness try to be on time more often".

PKP 3 "I was on time to submit SPT, although sometimes delays in network problems".

From the interview results, it can be seen that the Taxable Entrepreneur has submitted a complete and timely tax return report, although sometimes there are obstacles that cause delays in reporting, one of which is network connection problems.

\section{Conclusions}


This study concludes that with the presence of VAT e-invoices, effectiveness and efficiency occur in increasing PKP compliance. This can be seen by the use of e-invoices to facilitate PKP so that they are able to carry out tax obligations (register, calculate, pay, and report) in a timely manner. The results of this study indicate that the application of e-invoicing within the Makassar South Tax Office has been effective. This is known from the achievement of the three indicators that include the accuracy of use, the results of use, and support the objectives. The application of e-invoicing within the Makassar South Tax Office is already efficient. It is known that seven indicators for measuring efficiency have been achieved. The interviewees' answers led to the fact that the application of e-invoices in South Makassar KPP was already efficient. As a reinforcement of the facts, there are additional indicators to measure efficiency, namely the comparison between the costs incurred for implementing e-invoices with the revenue or benefits felt by the Tax Office. From Waskon 1's answer, it can be concluded that the costs incurred are smaller or cheaper than tax revenue, tax revenue has increased. The effectiveness and efficiency of implementing VAT e-invoices increases PKP compliance. This can be seen from the PKP's answer which leads that the use of e-invoices provides convenience so that they are able to carry out tax obligations (register, calculate, pay, and report) in a timely manner. Several interviews stated that the constraints to using e-invoicing were internet connection problems, as well as applications that sometimes occurred error.

The results of this study suggest that the role of the South Makassar KPP tax officer increases the level of awareness and honesty for taxable entrepreneurs in order to be able to report taxes according to the specified time. South Makassar Primary Tax Office is expected to be able to provide taxable business socialization to the use of e-invoice applications and to invite taxpayers to carry out their tax obligations without being penalized for violating existing regulations.

\section{References}

Allolayuk, T. (2018). Pengaruh Penerapan Aplikasi e-Faktur terhadap Kepatuhan Pengusaha Kena Pajak. Akuntansi \& Keuangan Daerah, 13(1), 148-157. http://ejournal.akuntansiuncen.ac.id/index.php/JurnalAkuntansiUncen/issue/view/5

Amah, N., Juniawati, \& Novitasari, R. A. (2010). Efektivitas Modernisasi Administrasi Pajak dan Kepatuhan Pajak. Seminar Nasional Hasil Penelitian Dan Pengabdian Masyarakat UNIPMA, 120-121.

Husnurrosyidah, H., \& Suhadi, S. (2017). Pengaruh E-Filing, E-Billing Dan E-Faktur Terhadap Kepatuhan Pajak Pada Bmt Se-Kabupaten Kudus. Jurnal Analisa Akuntansi Dan Perpajakan, 1(1), 97-106. https://doi.org/10.25139/jaap.v1i1.99

I Putu Gede Diatmika, S. (2017). Pengaruh Intensitas Tax Audit, Penerapan E-Faktur, Tax Knowledge, Dan Compliance Cost Terhadap Persepsi Etis Pengusaha Kena Pajak Tentang Tax Evasion Pada Kpp Pratama Singaraja. JIMAT (Jurnal Ilmiah Mahasiswa Akuntansi S1), 8(2). https://doi.org/10.23887/jimat.v8i2.14404

Lexy, J. Moleong. (2010). Metodologi Penelitian Kualitatif.

James, S., \& Nobes, C. (1996). The economics of taxation: Principles. Policy and Practice, 97.

Lintang, K., \& Pusung, R. (2017). Analisis Penerapan E-Faktur Pajak Dalam Upaya Meningkatkan Kepatuhan Pengusaha Kena Pajak Untuk Pelaporan Spt Masa Ppn Pada Kpp Pratama Manado. Jurnal EMBA: Jurnal Riset Ekonomi, Manajemen, Bisnis Dan Akuntansi, 5(2), 2023-2032.

Mardiasmo, D., \& MBA, A. (2009). Akuntansi Sektor Publik. Yogyakarta: ANDI.

Nurjanah, M., Diatmika, P. G., \& Yasa, I. N. P. (2017). Pengaruh Profitabilitas, Capital Intensity Ratio, Size, Dan Leverage Perusahaan Pada Manajemen Pajak. Jurnal Akuntansi.

Pandiangan, L. (2014). Administrasi perpajakan. Jakarta: Erlangga.

Prahaji, M. (2013). Analisis Penerapan Elektronik Nomor Faktur Sebagai Upaya Untuk Mencegah Penerbitan Faktur Pajak Fiktif. Journal of Chemical Information and Modeling, 53(9), 1689-1699. https://doi.org/10.1017/CBO9781107415324.004

Prahaji, M., Husaini, A., \& Darono, A. (2015). Analisis Penerapan Elektronik Nomor Faktur Sebagai Upaya Untuk Mencegah Penerbitan Faktur Pajak Fiktif. Jurnal Administrasi Bisnis - Perpajakan (JAB), 5(1), 01-10. https://doi.org/10.1017/CBO9781107415324.004

Rahayu, S. K., \& Suhayati, E. (2010). Perpajakan Teori dan Teknis Perhitungan. Yogyakarta: Graha Ilmu, 139.

Rahayu, S., \& Lingga, I. S. (2009). Pengaruh Modernisasi Sistem Administrasi Perpajakan Terhadap Kepatuhan 
Wajib Pajak (Survei Atas Wajib Pajak Badan Pada KPP Pratama Bandung "X”). Jurnal Akuntansi, 1(2), 119138. https://doi.org/10.28932/jam.v1i2.375

Resmi, S. (2014). Perpajakan Teori dan Kasus Edisi 4. Jakarta: Salemba Empat.

Rifani, R. A., Mursalim, M., \& Ahmad, H. (2019). Pengaruh Keadlilan, Sistem Perpajakan dan Kualitas Pelayanan Terhadap Penggelapan Pajak. PARADOKS: Jurnal Ilmu Ekonomi, 2(3), 131-144.

Said, S., \& Aslindah, A. (2018). Pengaruh Penerapan E-System Perpajakan Terhadap Kepatuhan Wajib Pajak Orang

Pribadi (Studi Pada KPP Pratama Makassar Selatan). ATESTASI: Jurnal Ilmiah Akuntansi, 1(1), 29-39.

Setyosari, H. P. (2016). Metode penelitian pendidikan \& pengembangan. Prenada Media.

Sudirman, \& Muslim, M. (2018). Analisis Faktor-faktor Yang Mempengaruhi Manajemen Perusahaan Melakukan Tax Planning. Center of Economic Student Journal, 1(1), 1-13.

Sulistyowati, N. W., Amah, N., \& Styaningrum, F. (2017). Analisis Efektivitas dan Efisiensi Penerapan E-Faktur PPN Guna Meningkatkan Kepatuhan Pengusaha Kena Pajak (Studi Pada PKP Terdaftar Di KPP Pratama Madiun). In Seminar Nasional dan The 5th Call for Syariah Paper, Universitas Muhammadiyah Surakarta.

Sugiyono, P. D. (2010). Metode penelitian pendidikan. Pendekatan Kuantitatif.

Syah, M. (2010). Psikologi pendidikan. Bandung: Remaja Rosdakarya.

Tahar, A., \& Kartika, A. Rachman, 2014 "Pengaruh Faktor Internal Dan Faktor Eksternal Terhadap Kepatuhan Wajib Pajak". Jurnal Akuntansi dan Investasi. Yogyakarta. Januari. Hal, 57-67.

Tiraada, T. A. (2013). Kesadaran perpajakan, sanksi pajak, sikap fiskus terhadap kepatuhan wpop di kabupaten minahasa selatan. Jurnal EMBA: Jurnal Riset Ekonomi, Manajemen, Bisnis dan Akuntansi, 1(3).

Widayati, N., \& Nurlis, A. (2010). Faktor-faktor Yang Mempengaruhi Kemauan Membayar Pajak Wajib Pajak Orang Pribadi Yang Melakukan Pekerjaan Bebas (Studi kasus pada KPP Pratama Gambir Tiga). Makalah Simposium Nasional Perpajakan XIII (yang dipresentasikan pada tahun 2010).

Widodo, W., Djefris, D., \& Wardhani, E. A. (2010). Moralitas, budaya, dan kepatuhan pajak. Alfabeta.

Yamin, L., \& Putranti, T. M. (2011). Model Penyelewengan Pajak Menggunakan Faktur Pajak Fiktif. Bisnis \& Birokrasi Journal, 16(1).

Yanto, M., \& Dewi, S. (2020). Analisis Pemahaman, Penerapan E-Faktur Dalam Pelaporan Pajak Pertambahan Nilai Pada CV. Kuat Jaya Mandiri Tanjung Pinang. Jurnal Economic, Accounting, Science, 1(2), 23-30. 